\title{
Uncertainty, Incentive and Over/Under-Investment
}

\author{
Honghui Zhang \\ School of Accountancy, Jiangxi University of Finance and Economics, Nanchang, China \\ Email: danordio@163.com
}

How to cite this paper: Zhang, H.H. (2017) Uncertainty, Incentive and Over/Under-Investment. Open Journal of Business and Management, 5, 450-457.

https://doi.org/10.4236/ojbm.2017.53038

Received: June 9, 2017

Accepted: July 4, 2017

Published: July 7, 2017

Copyright $\odot 2017$ by author and Scientific Research Publishing Inc. This work is licensed under the Creative Commons Attribution International License (CC BY 4.0).

http://creativecommons.org/licenses/by/4.0/

\begin{abstract}
This paper focuses on the impact of environmental uncertainty on investment efficiency, taking into account the effect of executive equity incentives on inefficient investments in opportunity investment set. Using the empirical data of listed companies, the study found that environmental uncertainty will increase investment efficiency and reduce over-investment level. Executive equity incentive will reduce the over-investment level and promote the lack of investment.
\end{abstract}

\section{Keywords}

Environmental Uncertainty, Executive Equity, Investment Efficiency

\section{Introduction}

Company investment is the project that company realizes the net present value, in order to obtain the future cash flow. But the existence of agency problems, will lead to inefficient investment in the company [1] [2]. Some domestic literatures, such as Xin [3] found when the remuneration contract was not enough to make up for managerial work, the company manager would make up for the lack of pay through excessive investment. Zhang and Zhu [4] have also come to similar conclusions. Government intervention can also lead to inefficient investment [5]; Zhang and Wang [6] argue that government control has led to the use of free cash flow by state-owned enterprises and over-investment. Huang and $\mathrm{Li}$ [7] have also come to similar conclusions.

Recently, some literatures began to realize that the uncertainty will also affect the company's inefficient investment. Shen Huihui et al. [8] studied the impact of environmental uncertainty on inefficient investment. Xu et al. [9] studied the impact of political uncertainty on private enterprise investment. However, these studies are concerned about the external uncertainty of the company's invest- 
ment efficiency, without considering the role of executive holdings on investment efficiency. In practice, in the presence of investment opportunities set, executives may increase their holdings, may also reduce the equity, which may affect the company's investment efficiency. Although Xu studied the impact of uncertainty on corporate investment from the perspective of equity incentive, arguing that equity incentive improves investment efficiency, it does not take into account the investment opportunities set factors; executives holdings are actually related to investment opportunities(it is meaningful to consider whether executive holdings affect investment efficiency in the investment opportunity set).

\section{Theoretical Review}

The agency problem caused by separation of ownership and control will make the company's management to maximize their own interests to replace the maximization of corporate value [1]. Inefficient investment is one of the forms of agency conflict, the management will accept the negative net present value project and continue to implement the project to build their own business empire when the company investment in a loss. Institutional environment can also affect the company's behavior [10], it will lead to the company's inefficient investment. Shleifer and Vishny [2] argue that government officials also have their own political goals. In order to obtain votes, they will use their own power to intervene in the operation of the business and increase the employment opportunities to please the voters through excessive investment.

Uncertainty also has an impact on the company's inefficient investment. In the company's investment decision-making, the NPV of the investment project needs to consider various parameters such as project cycle, discount rate, future cash inflow, etc. The uncertainty of the macro environment undermines the ability of executives to predict the firm-specific information [11], which leads to the difficulty of executives in estimating these parameters, will influence executive decision making, so that executives can not effectively identify investment opportunities and become more cautious in making investment decisions [13]. On the other hand, environmental uncertainty can also affect corporate finance. Environmental uncertainty may lead to uncertainty about the future cash flow of the company, which is an important source of corporate finance and an important factor in the company's investment. Environmental uncertainty can also affect the risk perception of creditors, creditors may require more risk exposure compensation, which will increase the company's financing capital costs and lead to the formation of financing constraints; creditors may also consider the environmental uncertainty, reducing the amount of loans and forming financing constraint. So the financial constraints caused by environmental uncertainty lead to a possible under-investment in the company [14], and may also inhibit overinvestment.

Executive holdings as a governance mechanism can mitigate agency problems [1]. Due to agency issues, corporate executives may abuse free cash flow, result- 
ing in over-investment. On the other hand, because of the investment in new projects, executives need new knowledge to manage the project, which increases the cost of executives. Executives may prefer to enjoying a quiet life and abandon the project.

\section{Research Design}

\subsection{Sample Selection}

In order to verify the hypothesis of the article and avoid the influence of the new accounting standards, this paper makes an empirical analysis using the data of listed companies in Shanghai and Shenzhen from 2007 to 2013. After obtaining all the listed company data in the CSMAR database, perform the following screening procedures: A. excluding listed companies with incomplete information from 2007 to 2013. B. excluding a year or years ST, PT listed companies. C. remove the companies with abnormal indicators. D. Excluding companies that issue B shares at the same time. Since it is necessary to measure the cash flow uncertainty, it needs to calculate the standard deviation of the company's first five years of data, so the final sample data is 3667 samples from 2011 to 2013.

\subsection{Measure Inefficient Investment}

Richardson's expected investment model is generally used to measure the inefficient investment, such as the previous Xin et al. [3], Zhang and Wang [5], which used this model to measure inefficient investment. The paper also uses this model to calculate the level of inefficiency investment. According to Richardson's expected investment model, the company's investment can be divided into two parts, one is the expected level of investment and the other is the level of unintended investment. The expected investment level is calculated as follows.

$$
\begin{aligned}
\text { invest }_{i, t}= & \alpha_{0}+\alpha_{1} \text { grow }_{i, t-1}+\alpha_{2} \text { lev }_{i, t-1}+\alpha_{3} \text { cashhld }_{i, t-1}+\alpha_{4} \text { age }_{i, t-1}+\alpha_{5} \text { size }_{i, t-1} \\
& +\alpha_{6} \text { return }_{i, t-1}+\alpha_{2} \text { invest }_{i, t-1}+\alpha_{3} \sum \text { year }+\alpha_{4} \sum \text { ind }+\varepsilon_{i, t}
\end{aligned}
$$

invest $_{i, t}$ is the level of investment that year, $\operatorname{lev}_{i, t-1}$ is the proportion of the previous year, grow $_{i, t-1}$ is the previous year's investment opportunities, age $e_{i, t-1}$ is the previous year's company listed age, cashhld $d_{i, t-1}$ is the previous year's cash holdings, size $_{i, t-1}$ is the size of the company last year, return ${ }_{i, t-1}$ is the company's stock returns last year, invest ${ }_{i, t-1}$ is the previous year's investment level, year is the annual effect, ind is the industry effect. When the actual investment level is subtracted from the expected level of investment, the residual of the model (1) is an inefficient investment. Some studies, such as Zhang and Wang [5], a negative portion of the residual $\varepsilon_{i, t}$ is expressed as under-investment, the residual positive part of $\varepsilon_{i, t}$ is expressed as over-investment. This approach does not take into account the problem of moderate investment, we will remove the upper $5 \%$ quantile of the parts with the negative residual, remaining residual sample as a lack of investment; Similarly, we will remove the next $5 \%$ quantile of the parts with the positive residual, remaining residual sample as an over-investment. 


\subsection{Define Equity Incentive}

Jensen [1] have pointed out that executive holdings can improve the level of synergies between executives and shareholders, reducing the behavior of executives seeking self-interest. Specific to the company's investment behavior, it may reduce the company executives inefficient investment behavior. However, Baum and Ozkan [11] pointed out that executive holdings are related to the company's future growth opportunities, and further argue that executive holdings are related to the company's Investment Opportunity Set.

$$
\begin{aligned}
\mathrm{OWN}= & \beta_{0}+\beta_{1} \mathrm{Ln}(\mathrm{S})+\beta_{2}[\mathrm{Ln}(\mathrm{S})]^{2}+\beta_{3} \mathrm{~K} / \mathrm{S}+\beta_{4}(\mathrm{~K} / \mathrm{S})^{2}+\beta_{5} \mathrm{Y} / \mathrm{S} \\
& +\beta_{6} \mathrm{SIGMA}+\beta_{7} \mathrm{~A} / \mathrm{TA}+\beta_{8} \mathrm{INV} / \mathrm{TA}+\beta_{9} \mathrm{MB}+\beta_{10} \mathrm{LEV} \\
& +\beta_{11} \sum \mathrm{IND}+\beta_{12} \sum \mathrm{YEAR}+\pi
\end{aligned}
$$

$\mathrm{OWN}$ is executive holding, $\mathrm{S}$ is operating income, $\mathrm{K}$ is total fixed assets, $\mathrm{Y}$ is operating profit plus depreciation, SIGMA is the annual standard deviation of stock return, A is sales cost, INV is total investment expenditure, IND is Industry dummy variable, YEAR is the annual dummy variable, $\pi$ is the residual term. Model (2) is actually to do regression analysis of executive holding through a number of factors, obtaining expected number of executive holding. The residual $\pi$ of regression analysis is the number of executive holding after we control the opportunity investment set, which we use Man to express. Nominally, it is the expected level of holdings; in fact, it is the proportion of spontaneous holdings that take into account the investment opportunities.

\subsection{Model Test}

$$
\begin{aligned}
\text { Uninv }= & \phi_{1}+\phi_{2} \text { Jeu }+\phi_{3} \text { Man }+\phi_{4} \text { Contl }+\phi_{5} \text { Turn }+\phi_{6} \text { Agency } \\
& +\phi_{7} \text { Size }+\phi_{8} \sum \text { year }+\phi_{9} \sum \text { ind }+\lambda
\end{aligned}
$$

In the model (2), Uninv is inefficient investment, Jeu is the environmental uncertainty, Man is the executive holdings considering the investment opportunity, Contl is the final control person type, Agency is the agency cost, Turn is asset turnover rate, Size is Company Size. Please see Table 1.

\section{Empirical Analysis}

(1) Determine the level of inefficient investment

Using the Richardson model, we can estimate the level of inefficient investment. Table 2 is the regression results for model (1). Among them, column (1) is the regression result using Tobin $\mathrm{q}$ as the investment opportunity, and the coefficients are significant except for the Tobin q coefficient. Column (2) is the regression result using total asset growth rate as the investment opportunity, and the coefficients are all significant. This is similar to result of Xin et al. [3], Zhang and Wang [5]. This shows that Tobin q said the company's investment opportunities are not very accurate, indicating that applicability of Tobin q in China is weak.

Table 3 is a descriptive statistic of variables. In order to facilitate the compar- 
Table 1. Definition and interpretation of variables.

\begin{tabular}{|c|c|c|}
\hline & $\begin{array}{l}\text { Variable } \\
\text { name }\end{array}$ & Variable interpretation \\
\hline $\begin{array}{l}\text { Dependent } \\
\text { variable }\end{array}$ & Uninv & $\begin{array}{l}\text { Inefficient investment, the negative residuals calculated using the } \\
\text { Richardson [12] expected investment model, after removing the 5\% } \\
\text { quantile is under-investment. The positive residuals calculated using the } \\
\text { Richardson [12] expected investment model, identified as } \\
\text { over-investment after excluding the 5\% quantile }\end{array}$ \\
\hline \multirow{3}{*}{$\begin{array}{l}\text { Explanatory } \\
\text { variables }\end{array}$} & Jeu & Environmental uncertainty, the use of Shen Huihui et al. [8] calculation \\
\hline & Man & $\begin{array}{c}\text { Equity incentive, expressed by executive holdings of investment } \\
\text { opportunities }\end{array}$ \\
\hline & Contl & $\begin{array}{l}\text { The ultimate control of human type, state-owned enterprises }=1 \text {, } \\
\text { private }=0\end{array}$ \\
\hline \multirow[t]{3}{*}{ Control variable } & Agency & $\begin{array}{c}\text { Agency costs, (management costs }+ \text { sales costs)/main } \\
\text { business income that }\end{array}$ \\
\hline & Size & Company size, expressed as the natural logarithm of total assets \\
\hline & Turn & Operational capacity, expressed in terms of asset turnover \\
\hline
\end{tabular}

Table 2. Measurement of inefficient investment levels.

\begin{tabular}{|c|c|c|}
\hline & (1) & (2) \\
\hline Constant & $\begin{array}{c}-0.095^{\star * *} \\
(-4.94)\end{array}$ & $\begin{array}{c}-0.069^{* * *} \\
(-3.84)\end{array}$ \\
\hline invest $_{t-1}$ & $\begin{array}{c}0.416^{* * *} \\
(47.84)\end{array}$ & $\begin{array}{c}0.402^{* * *} \\
(42.10)\end{array}$ \\
\hline grow $_{t-1}$ & & $\begin{array}{c}0.0146^{* * *} \\
(3.66)\end{array}$ \\
\hline$Q_{t-1}$ & $\begin{array}{l}0.002 \\
(1.61)\end{array}$ & \\
\hline $\operatorname{age}_{t-1}$ & $\begin{array}{c}-0.001^{* * *} \\
(-5.61)\end{array}$ & $\begin{array}{c}-0.001^{*} \\
(-5.36)\end{array}$ \\
\hline $\operatorname{size}_{t-1}$ & $\begin{array}{c}0.006^{* * *} \\
(7.25)\end{array}$ & $\begin{array}{c}0.005^{* * *} \\
(6.48)\end{array}$ \\
\hline $\operatorname{lev}_{t-1}$ & $\begin{array}{c}-0.029^{* * *} \\
(-6.21)\end{array}$ & $\begin{array}{c}-0.034^{* * *} \\
(-7.12)\end{array}$ \\
\hline cashhld $_{t-1}$ & $\begin{array}{c}-0.029^{* * *} \\
(-6.21)\end{array}$ & $\begin{array}{c}0.037^{* * *} \\
(5.26)\end{array}$ \\
\hline return $_{t-1}$ & $\begin{array}{c}0.006^{* * *} \\
(4.06)\end{array}$ & $\begin{array}{c}0.006^{* * *} \\
(4.37)\end{array}$ \\
\hline IND & control & control \\
\hline YEAR & control & control \\
\hline $\mathrm{R} 2$-adjj & 0.293 & 0.294 \\
\hline $\mathrm{F}$ & $111.11^{* * *}$ & $111.53^{\star * \star}$ \\
\hline
\end{tabular}

Note: ${ }^{* * *},{ }^{* *}$ and ${ }^{\star}$ represent $1 \%, 5 \%$ and $10 \%$ significance levels.

ison of environmental uncertainty and the effect of executive equity incentive on investment efficiency, we standardize the two variables of environmental uncertainty Jeu and executive equity incentive Man. As shown in Table 3. We can see that the maximum investment efficiency of Uninv is 0.5941 , which means that the unexpected investment exceeds the amount of expected investment in total assets is $59.41 \%$; the minimum value is -0.2376 , which means that the unexpected investment is lower than the amount of expected investment in total as 
Table 3. Descriptive statistics of variables.

\begin{tabular}{cccccc}
\hline Variable & Obs & Mean & Std. Dev. & Min & Max \\
\hline Uninv & 3667 & -0.0004 & 0.0545 & -0.2376 & 0.5941 \\
Jeu & 3667 & 1.2261 & 1.0776 & 0.0586 & 11.2025 \\
Man & 3667 & -0.0160 & 0.0777 & -0.1803 & 0.5683 \\
Turn & 3667 & 0.7928 & 0.6188 & 0.0159 & 8.9242 \\
Size & 3667 & 21.9162 & 1.2743 & 18.1624 & 28.4052 \\
Contl & 3666 & 0.5551 & 0.4970 & 0.0000 & 1.0000 \\
Agency & 3667 & 0.1465 & 0.1165 & 0.0052 & 0.9327 \\
\hline
\end{tabular}

sets accounted for $23.76 \%$. Jeu is environmental uncertainty, we can see its maximum value of 11.2025 , means that some companies face high environmental uncertainty; the minimum value is 0.0586 , means that some companies face the degree of environmental uncertainty is very weak. In other variables, the standard deviation of the firm size is 1.2743 , indicating that the difference between the size of the company is relatively large. Similarly, the standard deviation of environmental uncertainty is 1.0776 , indicating that the environmental uncertainty between the company is quite different.

Table 4 is the regression results. We can see some regression coefficients of environmental uncertainty are significant and some are not significant. The significant coefficients all belong to the over-investment regression part. The significance level of Jeu regression coefficient is 2 stars, the regression coefficient is -0.003 or so, indicating that the environmental uncertainty increase each $1 \%$, the degree of investment decline by $0.3 \%$. In the under-investment part, the regression coefficient of environmental uncertainty is not significant, and the regression coefficient is about -0.0002 , which indicates that environmental uncertainty has no effect on investment. Executive equity incentive Man's regression coefficient is significant, in the under-investment part, the significance level of executive equity incentive is 3 stars; in the over-investment part, the significance level of executive equity incentive is 1 star. Executive equity incentive Man's regression coefficient in the under-investment part is -0.0017 , means that the proportion of executives holdings increase each $1 \%$, under-investment will increase $0.17 \%$; executive equity incentive Man's return coefficient in the over-investment part is -0.0026 or so, means that the proportion of executives holdings increase each $1 \%$, the over-investment will reduce $0.26 \%$. In the regression (3) and regression (6), we put the environmental uncertainty and the executive equity incentive into the regression at the same time, which is used to compare the difference in the influence on the investment efficiency between the environmental uncertainty and executive holding incentive. We can see from the regression (3) that the environmental uncertainty of under-investment is not significant. the two variables in the over-investment part of regression (6) are significant. We can see from regression coefficient, the regression coefficient of the environmental uncertainty is greater, which means that the effect of environmental un- 
Table 4. Environmental uncertainty, equity incentives and investment efficiency.

\begin{tabular}{ccccccc}
\hline under- & $\begin{array}{c}\text { under- } \\
\text { investment }\end{array}$ & $\begin{array}{c}\text { under- } \\
\text { investment }\end{array}$ & $\begin{array}{c}\text { Over- } \\
\text { investment }\end{array}$ & $\begin{array}{c}\text { Over- } \\
\text { investment }\end{array}$ & $\begin{array}{c}\text { Over- } \\
\text { investment }\end{array}$ \\
\hline Con & $(1)$ & $(2)$ & $(3)$ & $(4)$ & $(5)$ & $(6)$ \\
\hline \multirow{2}{*}{ Jeu } & $-0.06315^{* * *}$ & $-0.0677^{* * *}$ & $-0.0663^{* * *}$ & $0.1093^{* * *}$ & $0.0984^{* * *}$ & $0.1012^{* * *}$ \\
& $(-6.43)$ & $(-6.79)$ & $(-6.74)$ & $(3.53)$ & $(3.19)$ & $(3.28)$ \\
Man & -0.0002 & & -0.0004 & $-0.0031^{* *}$ & & $-0.0034^{* *}$ \\
& $(-0.49)$ & & $(-0.70)$ & $(-1.99)$ & & $(-2.04)$ \\
Contl & $0.0032^{* * *}$ & $0.0024^{* *}$ & $0.0024^{* *}$ & $-0.0106^{* * *}$ & $-0.0115^{* * *}$ & $-0.0118^{* * *}$ \\
& $(2.89)$ & $(2.17)$ & $(2.12)$ & $(-3.23)$ & $(-3.41)$ & $(-3.50)$ \\
Agency & 0.0010 & 0.0016 & 0.0015 & $-0.0349^{* *}$ & $-0.0341^{* *}$ & $-0.0336^{* *}$ \\
& $(0.21)$ & $(0.34)$ & $(0.31)$ & $(-2.39)$ & $(-2.32)$ & $(-2.30)$ \\
Turn & -0.0010 & -0.0009 & -0.0009 & -0.0019 & -0.0013 & -0.0018 \\
& $(-1.19)$ & $(-1.01)$ & $(-1.10)$ & $(-0.68)$ & $(-0.49)$ & $(-0.66)$ \\
Size & $0.0015^{* * *}$ & $0.0017^{* * *}$ & $0.0017^{* * *}$ & -0.0021 & -0.0018 & -0.0019 \\
& $(3.47)$ & $(3.86)$ & $(3.83)$ & $(-1.54)$ & $(-1.31)$ & $(-1.39)$ \\
Year & Yes & Yes & Yes & Yes & Yes & Yes \\
Ind & Yes & Yes & Yes & Yes & Yes & Yes \\
Ad-r2 & 0.0121 & 0.0165 & 0.0163 & 0.0120 & 0.0110 & 0.0133 \\
F & $6.57^{* * *}$ & $8.64^{* * *}$ & $7.28^{* * *}$ & $4.37^{* * *}$ & $4.08^{* * *}$ & $4.10^{* * *}$ \\
$\mathrm{~N}$ & 2281 & 2281 & 2281 & 1385 & 1385 & 1385 \\
\hline
\end{tabular}

Note: ${ }^{* * *},{ }^{* *}$ and ${ }^{*}$ represent $1 \%, 5 \%$ and $10 \%$ significance levels.

certainty on the excessive investment is greater than the equity incentive.

In the control variable, the regression coefficient of the final control person type Contl is significant. In the under-investment part, the regression coefficient is positive, which indicates that the state-owned enterprises' under-investment level is less than the private enterprises. The agency cost Agency's regression coefficient is not significant in under-investment, which is significant in overinvestment, indicating that agency costs will reduce the over-investment level. Turnover of assets Turn is not significant in under-investment and over-investment, indicating that asset turnover has no effect on investment efficiency. The size of the firm Size is significant in under-investment and is not significant in over-investment, indicating that asset size has an impact on under-investment.

\section{Conclusion and Revelation}

This study found that environmental uncertainty will affect the efficiency of investment; environmental uncertainty will reduce the excessive investment, confirming the Shen [8] conclusions. The executive holdings that take into account the investment opportunities set will not only reduce the over-investment, but also lead to under-investment, suggesting that equity incentives will lead executives prefer a quiet life, confirming Bertrand and Mullainathan (2003). At the same time there are environmental uncertainty and equity incentives; environ- 
mental uncertainty can inhibit excessive investment greater, which shows that uncertainty is sometimes a good thing; it can inhibit over-investment. The results of this paper show that environmental uncertainty can inhibit over-investment, so increasing environmental uncertainty can improve investment efficiency. Reasoning to reality, the free competition of the industry environment is more uncertain, monopoly industry environment, low uncertainty. Therefore, to increase market competition, break the monopoly is one way to improve the efficiency of the company. At the same time, we should also pay attention to the duality of executive holdings. For over-invested companies, the grant of equity will help to improve the efficiency of investment. For under-invested companies, the equity will not have a positive effect. At this time other incentives, such as cash compensation incentives, job promotion incentives and so on should be considered.

\section{References}

[1] Jensen, M. (1986) Agency Costs of Free Cash Flow, Corporate Finance, and Takeovers. American Economic Review, 76, 323-329.

[2] Shleifer, A. and Vishny, R. (1989) Management Entrenchment: The Case of Manager-Specific Investments. Journal of Financial Economics, 25, 123-139. https://doi.org/10.1016/0304-405X(89)90099-8

[3] Xin, Q.Q. and Lin, B. (2007) Government Control, Managerial Compensation and Capital Investment. Journal of Economic Research, 8, 110-122. (in Chinese)

[4] Zhang, L. and Zhu, G.H. (2014) Soes' Compensation and Corporate Over-Investment. Shanghai Economic Review, 1, 63-69. (in Chinese)

[5] Shleifer, A. and Vishny, R. (1994) Politicians and Firms. Quarterly Journal of Economics, 109, 995-1025. https://doi.org/10.2307/2118354

[6] Zhang, H.H. and Wang, Z.J. (2010) Government Incentive, Government Goal and Soes' Over-Investment. Nankai Business Review, 3, 101-108. (in Chinese)

[7] Huang, J. and Li, Z.Q. (2014) Government Intervention, Corporate Employment and Over-Investment. Journal of Finance Research, 8, 118-130. (in Chinese)

[8] Shen, H.H. and Yu, P. (2012) State Ownership, Environment Uncertainty and Investment Efficiency. Journal of Economic Research, 7, 113-126. (in Chinese)

[9] Xu, Q. (2014) Uncertainty, Share Incentive and Inefficient Investment. Journal of Accounting Research, 3, 41-49. (in Chinese)

[10] La Porta, R., Lopez-de-Silanes, F., et al. (1998) Law and Finance. Journal of Political Economy, 106, 1113-1155. https://doi.org/10.1086/250042

[11] Baum, C., Ozkan, N., et al. (2006) The Impact of Macroeconomic Uncertainty on Non-Financial Firms' Demand for Liquidity. Review of Financial Economics, 15, 289-304.

[12] Richardson, S. (2006) Over-Investment of Free Cash Flow. Review of Accounting Studies, 11, 159-189. https://doi.org/10.1007/s11142-006-9012-1

[13] Baum, C.E.A. (2007) Uncertainty Determinants of Firm Investment. Working Paper, SSRN.

[14] Bhagat, S. and Obreja, I. (2013) Employment, Corporate Investment and Cash Flow Uncertainty. SSRN, Working Paper. 
Submit or recommend next manuscript to SCIRP and we will provide best service for you:

Accepting pre-submission inquiries through Email, Facebook, LinkedIn, Twitter, etc. A wide selection of journals (inclusive of 9 subjects, more than 200 journals)

Providing 24-hour high-quality service

User-friendly online submission system

Fair and swift peer-review system

Efficient typesetting and proofreading procedure

Display of the result of downloads and visits, as well as the number of cited articles Maximum dissemination of your research work

Submit your manuscript at: http://papersubmission.scirp.org/

Or contact ojbm@scirp.org 